\title{
US Army to dispose of ageing chemical weapons on-site
}

Washington

AFTER years of debate, the US Army finally conceded last week that disposing of its ageing stockpile of single-agent, or unitary, chemical weapons at the sites where they are stored is preferable to transporting them to a single national incineration facility. Critics had raised the spectre of an accident en route with catastrophic consequences.

The Army has wanted since the early 1980 s to exchange its unitary chemical weapons for newer binary weapons because the unitary stockpiles are ageing and in danger of leaking. Binary weapons are intrinsically safer, because they are made from two chemical agents that are individually safe and only become toxic when mixed.

Although the precise size of the chemical weapons stockpiles is classified, 30,000 tons is a reasonable estimate. Approximately half that amount is mustard gas, a skin-blister agent, and the other half is nerve gas. Approximately 65 per cent of the chemical inventory is stored in one-ton steel containers, the rest in weapons: projectiles, cartridges, mines and rockets containing propellants.

In 1985, Congress authorized the Army to begin acquiring the materials it needed for the new weapons, but delayed plans to assemble them until 1987. At the same time, Congress required the Army to develop plans for destroying its unitary stockpiles. By law, the "demilitarization" process should be complete by 1994 .

But destroying the weapons has been a thorny problem, for both political and technical reasons. The Army's initial plan for a single incinerator met with opposition from a Congress worried about an accident during transport of the weapons from the eight storage arsenals.

On-site incineration will also be politically difficult. States and local communities may have grown accustomed to being the resting place for weapons, but being their burial ground is another issue.

\section{Guide to Europe}

\section{London}

THE Science and Engineering Policy Studies Unit of the Royal Society has produced a guide entitled European Collaboration in Science and Technology which gives details of one hundred schemes for promoting research collaboration within Europe. The guide costs $£ 25$ and is available from the publication sales department of the Royal Society, 6 Carlton House Terrace, London SW1Y 5AG, UK.

Simon Hadlington
The Army also ran into engineering problems in demilitarizing its stockpiles. A pilot incinerator at the Tooele Army Depot in Utah had to be shut down last year after it developed a leak. An alternative incineration method called "cryofracture" - where weapons are frozen and then handled by robots - has not yet been sufficiently successful to be relied upon, although the Army will continue to develop the process. There is also the problem that incineration itself will generate toxic by-products. Under the current plan, the weapons will be incinerated after partial disassembly. The inert ash will then be transported to an as-yet undetermined burial site.

But disposing of the weapons is expensive and time-consuming. It will cost between $\$ 2,000$ million and $\$ 3,000$ million, and even in the unlikely event that there are no further political or technical snags, the Army estimates that it cannot finish the project before 1996.

There are also no plans as yet for dealing with the weapons currently stored in West Germany. The German government has indicated that it would like the weapons removed.

If the Army has been forced to delay its timetable for destroying old weapons, at least it was able to begin building new ones on schedule. The first $155-\mathrm{mm}$ artillery shells using binary nerve gas came off the assembly line last December.

Impetus for developing techniques for destroying chemical weapons also comes from improved prospects for a treaty that would ban all chemical weapons. At present the Geneva Protocol of 1925 bans the use of chemical weapons in war, but does not prohibit countries from producing them. The United States has vowed never to be the first to use such weapons in combat. A draft chemical weapons treaty is being developed in multilateral arms control talks in Geneva, and bilateral technical discussions are also under way with the Soviet Union. Any treaty would undoubtedly call for the destruction of existing stockpiles.

Joseph Palca

\section{Call for international treaty to protect genetic diversity}

\section{San Jose, Costa Rica}

DEMANDS for an international treaty to protect the world's genetic diversity were made at the meeting of the International Union for the Conservation of Nature and Natural Resources (IUCN), an organization of scientists, governments and nongovernmental bodies, held last month in Costa Rica.

The draft treaty won the backing of the 1,000 or so participants at the conference It proposes protecting sites with high biological diversity using funds generated by a levy on commercial and industrial users of genetic material. It would also give countries the right to impose "reasonable charges" on the use of genetic material, a condition designed to please developing countries which want compensation for banning development in species-rich areas.

The complicated issue of compensation has been under discussion by the United Nations Food and Agriculture Organisation for several years, without clear result. The IUCN suggests charging profit-making individual companies or industry-wide groups of companies either as a fixed sum or as a percentage of profits.

Guaranteed rights of access to genetic material for pure or applied research and for genetic engineering are also provided for in the draft treaty, although questions of whether countries actually own endemic species are not addressed.

Scientists in the IUCN argue that genetic resources are better protected in situ, by preserving species in their natural habitat to protect the full range of genetic variability, an advantage not shared by conservation in gene banks, botanic gardens or zoos. Thus the emphasis is on conservation of habitats, and on obtaining funds for that purpose.

Participants also discussed preserving genetic diversity in developing countries through a "debt for conservation" plan, where banks are asked to donate bad debt to developing countries for use in conservation projects. Such a scheme is already under way in Bolivia (see Nature 328, 373; 1987).

At least two international banks are seriously considering donating more than $\$ 1$ million to Costa Rica for conservation, according to Costa Rica's Minister of Natural Resources, Dr Alvaro Umana. The Costa Rican Central Bank has agreed to pay 75 cents on the dollar for debt notes, in local currency, if the money is put into conservation projects. Costa Rica's government hopes to use the donations to restore more than 70,000 hectares of degraded pastureland to tropical dry forest in the Guancaste region.

Costa Rica's president, Dr Oscar Arias, winner of the Nobel Peace prize, told the conference that preserving genetic diversity is especially important for biotechnology which can solve some of the most urgent problems of developing countries. Kathy Johnston 